\title{
Geological evidence for shallow ductile-brittle transition zones along subduction interfaces: example from the Shimanto Belt, SW Japan
}

\author{
Yoshitaka Hashimoto* and Natsuko Yamano
}

\begin{abstract}
Tectonic mélange zones within ancient accretionary complexes include various styles of strain accommodation along subduction interfaces from shallow to deep. The ductile-brittle transition at shallower portions of the subduction plate boundary was identified in three tectonic mélange zones (Mugi mélange, Yokonami mélange, and Miyama formation) in the Cretaceous Shimanto Belt, an on-land accretionary complex in southwest Japan. The transition is defined by a change in deformation features from extension veins only in sandstone blocks with ductile matrix deformation (possibly by diffusion-precipitation creep) to shear veins (brittle failure) from shallow to deep. Although mélange fabrics represent distributed simple to sub-simple shear deformation, localized shear veins are commonly accompanied by slickenlines and a mirror surface. Pressure-temperature (P-T) conditions for extension veins in sandstone blocks and for shear veins are distinct on the basis of fluid inclusion analysis. For extension veins, P-T conditions are approximately 125 to $220^{\circ} \mathrm{C}$ and 80 to $210 \mathrm{MPa}$. For shear veins, P-T conditions are approximately 185 to $270^{\circ} \mathrm{C}$ and 110 to $300 \mathrm{MPa}$. The P-T conditions for shear veins are, on average, higher than those for extension veins. The temperature conditions overlap in the range of approximately 175 to $210^{\circ} \mathrm{C}$, which suggests that the change from more ductile to brittle processes occurs over a range of depths. The width of the shallow ductile-brittle transition zone can be explained by a heterogeneous lithification state for sandstone and mudstone or high fluid pressure caused by clay dehydration, which is controlled by the temperature conditions.
\end{abstract}

Keywords: Shallow ductile-brittle transition zone; Tectonic mélange; Shear vein; Pressure-temperature condition; Accretionary complex; Shimanto Belt

\section{Findings Introduction}

The physical properties of sediments evolve during underthrusting along subduction thrust interfaces because of mechanical (e.g., compaction) and chemical (e.g., dehydration and cementation) processes (e.g., Moore and Saffer, 2001). Each of these components of the lithification process can contribute to changes in deformation features and deformation mechanisms (Knipe, 1989). The evolution of physical properties of sediments associated with changes in deformation features and deformation mechanisms are reflected in both wedge geometry and the kinematics of earthquakes brought on by changes in the

\footnotetext{
* Correspondence: hassy@kochi-u.ac.jp

Department of Applied Science, Faculty of Science, Kochi University, Akebonocyo 2-5-1, Kochi 780-0915, Japan
}

mechanical behavior of wedge materials and plate boundaries (e.g., Wang and $\mathrm{Hu}, 2006$ ).

The seismogenic zone has been described as the temperature-controlled zone of plate boundary coupling, where interplate earthquakes nucleate (e.g., Hyndman and Wang, 1993). Recently, additional types of failure have been found along active subduction zones, such as slow slip events (e.g., Hirose et al., 1999; Kato et al., 2012; Ito et al., 2013), episodic tremor and slip (e.g., Rogers and Dragert, 2003; Obara et al., 2004, Ishida et al., 2013), very low frequency earthquakes (e.g., Ito and Obara, 2006; Sugioka et al., 2012), and dynamic overshoot to the trench axis (e.g., Ide et al., 2011). Studies have been conducted to connect geologic deformation features from on-land accretionary complexes with seismic and aseismic deformations or with the newly found failure styles (e.g., Ikesawa et al., 2003; Kimura et al., 2007; Meneghini et al., 2010; 
Fagereng and Toy, 2011; Saito et al., 2013). Pseudotachylyte and fluidized shear zones, which indicate dynamic weakening of the fault during displacement, were found in on-land accretionary complexes; this suggests that the geologic features of the seismogenic slips along subduction interfaces are visible in on-land accretionary complexes (e.g., Ikesawa et al., 2003; Kitamura et al., 2005; Ujiie et al., 2007; Meneghini et al., 2010; Hashimoto et al., 2012; Saito et al., 2013). Further detailed studies of onland accretionary complexes are needed to understand the nature of deformation features and how they relate to variable slip styles along subduction plate interfaces.

The evolution of deformation features and deformation mechanisms along subduction zones has been revealed from on-land geology in exhumed accretionary complexes, not only in the Shimanto Belt (e.g., summarized in Kimura et al., 2007) but also in other accretionary complexes (e.g., Fisher and Byrne, 1987; Fagereng and Toy, 2011; Rowe et al., 2013). By reviewing many previous studies, Fagereng and Toy (2011) pointed out that ductile flow by diffusion-precipitation creep and cataclastic deformation coexist as the major deformation mechanisms in seismogenic crust. The spatiotemporal relation between plastic and brittle deformations, however, has been expressed as deformations in a heterogeneous mélange rheology (e.g., Fagereng and Sibson, 2010). Extension veins related to mélange fabrics and shear veins cutting the mélange fabrics have been well documented, with detailed pressure-temperature conditions from the Mugi mélange, Miyama formation, and Yokonami mélange in the Cretaceous Shimanto Belt (e.g., Hashimoto et al., 2002, 2003; Matsumura et al., 2003; Hashimoto et al., 2012) (see locations in Figure 1); these data can be a key in understanding the relation between ductile deformation for mélange and brittle failure (shear veins) in lithified shale matrices. In this study, we summarize the differences between observed deformation features and inferred deformation mechanisms for ductile mélange and shear vein formations in detail, with reference to published pressuretemperature conditions. We propose that the shallow ductile-brittle transition zone is reflected by the change from extension veins within sandstone lenses contained in ductile shale matrices to shear veins in brittle shale matrices. Finally, we discuss the interpretation of the ductile-brittle transition zone in shallower portions of the subduction plate interface.

\section{Tectonic mélanges}

Mélanges are characteristic components of on-land accretionary complexes. A mélange is defined as a mapscale geologic body with coherent blocks in a sheared matrix texture. Blocks are composed mainly of sandstone or oceanic material such as basalt or cherts, and the blocks are surrounded by a shale matrix (Figure 2A). The thickness of the mélange zone in the Shimanto complex is typically less than $1 \mathrm{~km}$ based on field observations for the mappable distribution of mélange zones (e.g., Taira et al., 1988). Rowe et al. (2013) determined the thickness of a shear zone along a subduction plate interface and found it to be up to a few hundred meters in thickness. Within the mélange zone, the same shear zones may be stacked up by duplex structures to form underplated accretionary complexes (e.g., Hashimoto and Kimura, 1999). The thickness of each horse of ocean floor stratigraphy has been reported to be up to a few hundred meters in the mélange zone focused on in this study

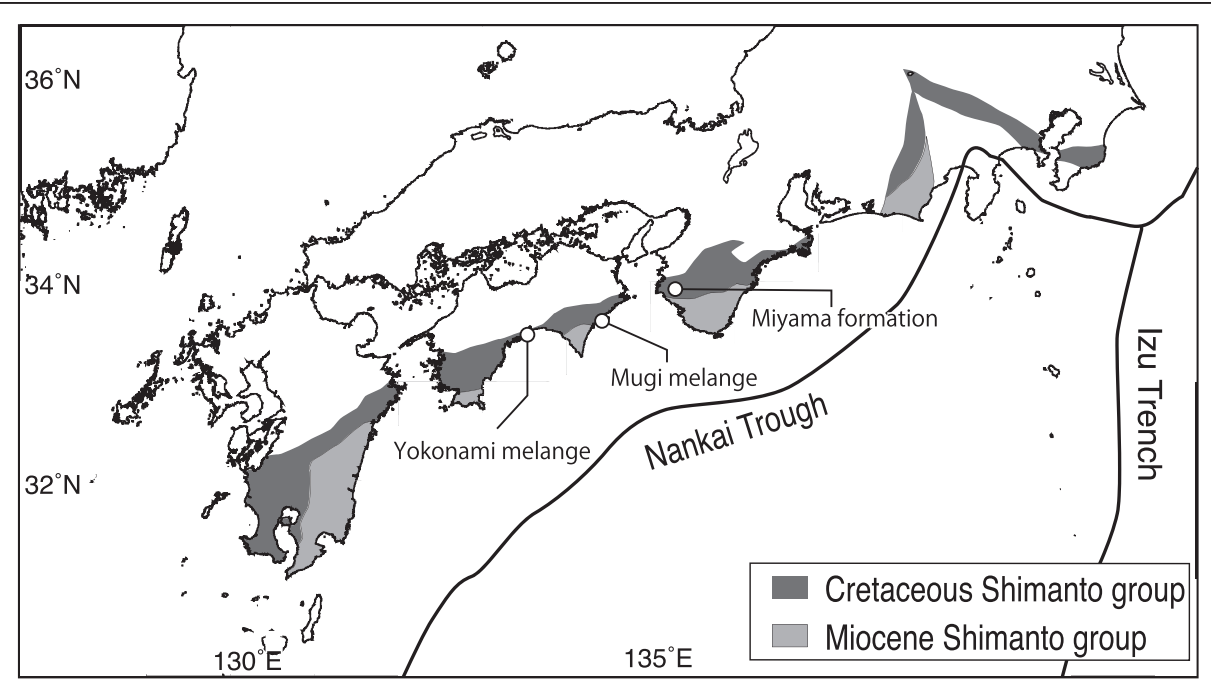

Figure 1 Distribution of the Shimanto Belt in central and southwest Japan. Locations of the Yokonami mélange, Mugi mélange, and Miyama formation are also represented. 

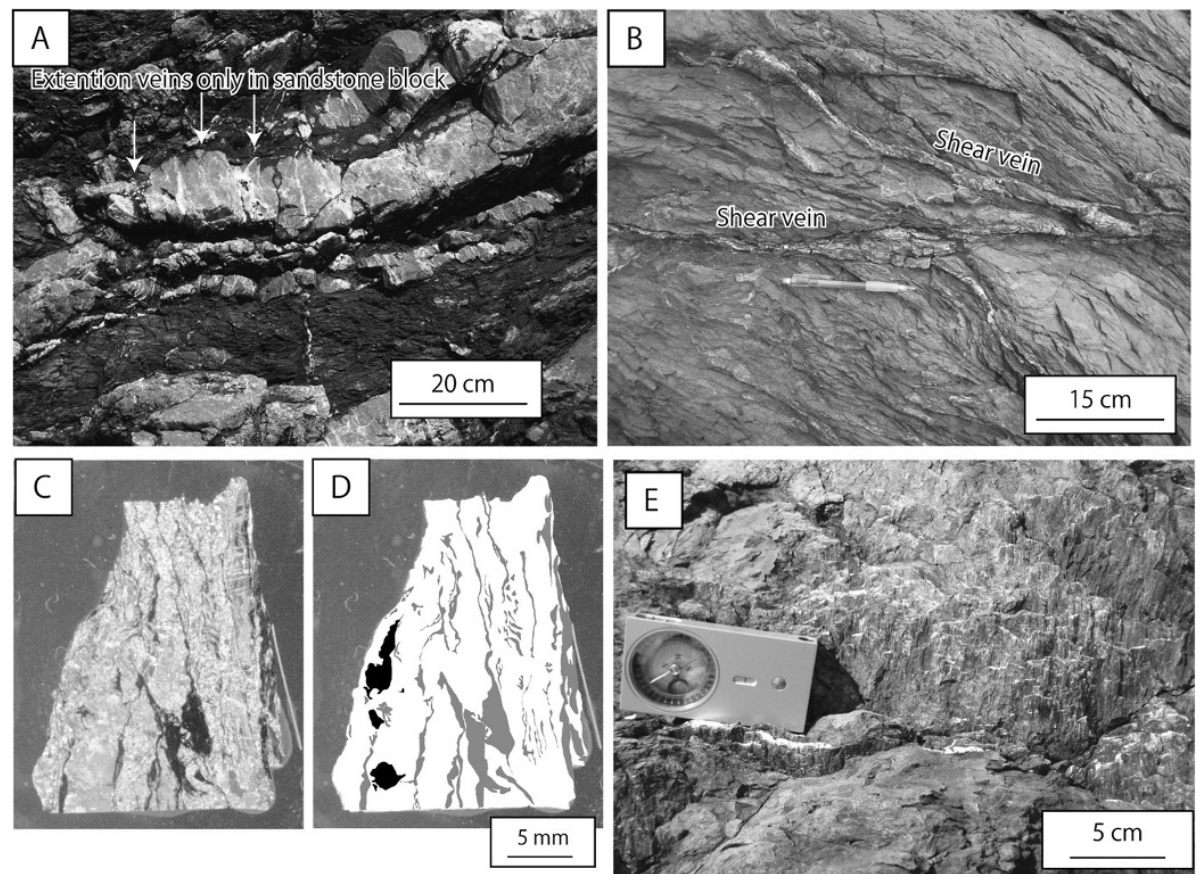

Figure 2 Textures of tectonic mélange showing sandstone blocks surrounded by shale matrix (A). Extension veins, which developed only in sandstone blocks, were observed. Scaly cleavages are well developed in the shale matrix. Shear veins cutting the shale matrix (B). Scanned image of a thin section of a shear vein under cross-polarized light (C). The scale is the same as Figure 2D. Sketch of Figure 2C (D). White, quartz; gray, clay layers; and black, calcite. Slickenlines and slickensteps on the shear vein surface $\mathbf{( E )}$

(Hashimoto and Kimura, 1999; Ikesawa et al., 2005; Hashimoto et al., 2012). Although mélanges have been suggested to be sedimentary, tectonic, and diapiric, most mélange zones in the Shimanto Belt are inferred to be tectonic mélanges (e.g., Kimura and Mukai, 1991; Onishi and Kimura, 1995; Hashimoto and Kimura, 1999), with some exceptions (Osozawa et al., 2009). The characteristics of tectonic mélanges are as follows: (1) the blocks have consistent asymmetric shapes and the surrounding shale matrices exhibit asymmetric flow textures around the blocks (asymmetric pressure shadow), without exclusively granular flow of sandstone, and (2) composite planar fabrics (generally called scaly fabrics) are well developed, especially in the shale matrices. The occurrence of composite planar fabrics in a mélange suggests that the mélange was formed by simple or sub-simple shear deformation. At the outcrop scale, the spacing of the scaly foliations is less than $1 \mathrm{~cm}$. However, much denser foliations can be identified at the microscopic scale in some parts.

The deformation mechanisms associated with mélange formation are commonly inferred on the basis of petrographic observations. Black seams are commonly observed along the composite planar fabrics at the microscopic scale (Figure 3A). The deformation mechanism for black seams has been interpreted as a pressure solution in previous studies on the basis of the similarity of stylolyte texture and dissolved radiolaria fossils with the black seams (e.g., Onishi and Kimura, 1995; Hashimoto and Kimura, 1999), which indicates that dissolution and precipitation creep contributed to mélange formation. This feature is the plastic strain at the outcrop scale. Extension veins developed only in the mélange blocks are observed pervasively at both the outcrop and the microscopic scales (Figure 2A) (Hashimoto et al., 2003). The extension veins are composed mainly of quartz and minor calcite. In some parts, shale is injected into the extension veins. Whereas the sandstone blocks were well-lithified and broken in a brittle manner, the shale matrix surrounding the sandstone blocks was deformed in a ductile manner. These occurrences suggest that a competence contrast existed at the time of the extension vein formation.

Pressure solution cleavages are composed of clay minerals approximately $0.5 \mu \mathrm{m}$ in diameter (Figure 3B). The grain size is relatively heterogeneous compared with that of the clay coatings on shear veins that will be described later. Authigenic pyrites (up to approximately $1 \mu \mathrm{m}$ ) are also observed in the cleavages as light white patches (Figure 3B). Energy dispersive X-ray spectrometry shows that the cleavages are composed of $\mathrm{Si}, \mathrm{Al}, \mathrm{K}$, and $\mathrm{C}$, and the $\mathrm{X}$-ray diffraction analysis indicates that the clay mineral present is illite, on the basis of the location of the white mica 001 peak. 

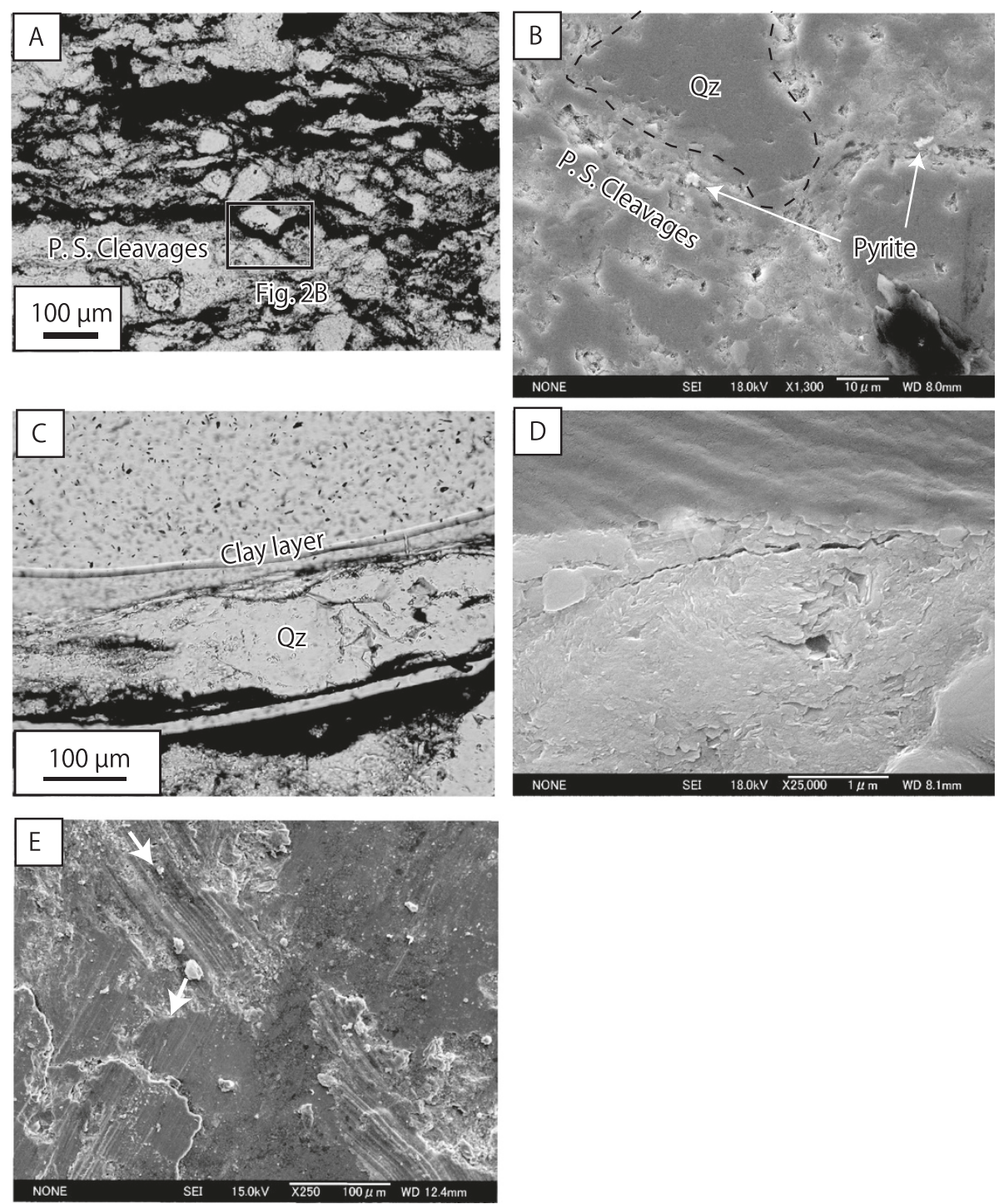

Figure 3 Pressure solution cleavage (PS cleavage) under the optical microscope (A). Scanning electron microscope (SEM) image of PS cleavage (pale light gray) (B). Dark gray grains are quartz grains (Qz). The location is shown in Figure 3A. Clay layer under the optical microscope (thin layer above the quartz vein (Qz) (C). Magnified SEM image of the clay layer composed of very fine (approximately $10 \mathrm{~nm}$ ) and well-sorted clay minerals (D). An SEM image of multiple directions of striations on the clay layer. White arrows indicate the two directions of striations (E).

\section{Shear veins}

Shear veins are commonly observed parallel or subparallel to the mélange foliation. In some parts, shear veins clearly cut the mélange foliation, which indicates that some of the shear veins were formed after the mélange formation (Figure 2B). The occurrence of foliations crosscutting shear veins is not observed at the outcrop scale. Displacement along the shear vein is relatively small, that is, less than $1 \mathrm{~m}$. Veins consist of quartz and calcite. Matsumura et al. (2003) and Hashimoto et al. (2012) presented the one-dimensional distribution of shear veins in the Mugi mélange and the Yokonami mélange, which are both in the Cretaceous Shimanto Belt, Shikoku Island. The number of shear veins in a 1-m interval perpendicular to the mélange foliations is approximately 2 to 3. Much larger densities of shear veins have been reported in the Chrystalls Beach complex, New Zealand (Fagereng, 2011a). The average thickness of shear veins ranges from 3 to $6 \mathrm{~mm}$. Multiple thin clay layers, parallel to the vein, are observed within the veins (Figure $2 \mathrm{C}, \mathrm{D}$ ). The thickness of the clay layers varies from a few tens of micrometers to a few millimeters. In the left side of the figure, the vein surface is represented by a relatively straight surface of clay layer; whereas the clay layers within the veins show wavy shapes (Figure 2C,D). This occurrence suggests that shear vein mineralization occurred repeatedly. On the surface of the shear veins, slickenlines and slickensteps are well observed, and clay 
coatings (weathered mirror surfaces) are also identified on them (Figures $2 \mathrm{E}$ and $3 \mathrm{C}$ ). The clay coatings are represented as a relatively shiny and thin black layer, and they are observed as an aggregate of nanoscale clay grains (Figure 3D). On the surfaces, slickenlines and slickensteps are also recognized (Figure 3D). Therefore, the deformation mechanism of shear veins is brittle failure.

\section{Pressure-temperature conditions}

Pressure-temperature conditions for the formations of the extension and the shear veins have been previously estimated on the basis of fluid inclusion analysis from three mélange zones in the Cretaceous Shimanto Belt: the Mugi mélange (Matsumura et al., 2003), the Miyama formation (Hashimoto et al., 2002, 2003), and the Yokonami mélange (Hashimoto et al., 2012) (see locations in Figure 1). For the Yokonami mélange, the pressure-temperature condition only for the shear veins was obtained. The host minerals for fluid inclusions are quartz and lesser calcite. Host mineral strain by crystal-plastic processes in relatively weak minerals such as calcites can alter the fluid inclusion density in ways that render homogenization temperature data difficult to use (Roedder, 1984), for example, fluidinclusion stretching during heating (Prezbindowski and Larese, 1987). The host mineral for fluid inclusion presented here is mostly quartz because the amount of calcite host is much less. No systematic variation in homogenization temperatures from calcite hosts has been noted suggesting that the constant density assumption for the trapped fluids is valid (e.g., Roedder, 1984).

The temperature conditions for the extension and the shear veins ranged from approximately 125 to $220^{\circ} \mathrm{C}$ (approximately 125 to $200^{\circ} \mathrm{C}$ for the Mugi mélange and approximately 150 to $220^{\circ} \mathrm{C}$ for the Miyama formation) and from approximately 185 to $270^{\circ} \mathrm{C}$ (approximately 135 to $245^{\circ} \mathrm{C}$ for the Mugi mélange, approximately 200 to $270^{\circ} \mathrm{C}$ for the Miyama formation, and approximately 185 to $225^{\circ} \mathrm{C}$ for the Yokonami mélange), respectively (Figure 4). The pressure conditions for the extension and the shear veins are approximately 80 to $210 \mathrm{MPa}$ (approximately 90 to $145 \mathrm{MPa}$ for the Mugi mélange, approximately 80 to $210 \mathrm{MPa}$ for the Miyama formation) and approximately 110 to $300 \mathrm{MPa}$ (approximately 110 to $150 \mathrm{MPa}$ for the Mugi mélange, approximately 145 to $300 \mathrm{MPa}$ for the Miyama formation, and approximately 140 to $215 \mathrm{MPa}$ for the Yokonami mélange), respectively (Figure 4). Average errors in temperature and pressure for each plot are approximately $\pm 25^{\circ} \mathrm{C}$ and approximately $\pm 10 \mathrm{MPa}$, respectively (Hashimoto et al., 2002, 2003; Matsumura et al., 2003; Hashimoto et al., 2012). Although the data are limited, the pressuretemperature condition for the Mugi mélange tends to shift to a higher thermal gradient, possibly because of the relatively young and hot plate subduction (Matsumura et al., 2003). The age of the subduction slab for the Mugi mélange is approximately 0 to 10 m.y., which is younger than the age of the slab for the Yokonami mélange and the Miyama formation (approximately 40 to 50 m.y.) (Taira et al., 1988). On the basis of the relation between slab age and heat flow (Parsons and Sclater, 1977), thermal gradients for the Mugi mélange and other mélanges can be estimated to be above approximately 55 and $30^{\circ} \mathrm{C} / \mathrm{km}$, respectively, at a thermal conductivity of $2.2 \mathrm{~W} / \mathrm{mK}$ and a density of $2.65 \mathrm{~g} / \mathrm{cm}^{3}$. Although the thermal conductivity can be significantly variable, the relative relation in the thermal gradient between the Mugi mélange and others may be similar in terms of their variable thermal conductivity. Most of the data fall within the thermal gradients between 30 and $60^{\circ} \mathrm{C} / \mathrm{km}$, except for the temperature range between approximately 175 and $220^{\circ} \mathrm{C}$ (Figure 4), if we assume that the fluid pressure is almost lithostatic. The variations in pressure-temperature (P-T) values may indicate fluctuations in the ratio of fluid pressure to lithostatic pressure. However, the temperature estimates from the fluid inclusions coincide with the peak temperature estimates from vitrininte reflectance (approximately 150 to $250^{\circ} \mathrm{C}$ ) (Ohmori et al., 1997), which suggests that the variations reflect real in situ temperatures. Variations in P-T may contain results from the drop in fluid pressure caused by dilatant deformation, as reported by Lewis and Byrne (2003).

The temperature gradient of up to $60^{\circ} \mathrm{C} / \mathrm{m}$ (Figure 4) is much higher than that predicted by subduction zone thermal modeling. This can possibly be explained by the pressure drop, which makes the geothermal gradient apparently higher. Because the geothermal gradient for the Mugi mélange is considered to be higher than those of the Miyama formation and the Yokonami mélange, the temperature range for the extension vein and shear vein formation can be shallower than those for the Miyama formation and the Mugi mélange. Nevertheless, the temperature condition of the extension veins for each mélange zone shows a similar range, although the data are limited in the Mugi mélange, and this suggests that the extension vein development may finish in a shallower portion in the higher geothermal gradient than that in the lower geothermal gradient.

The average temperature condition for the extension veins is slightly lower (approximately $50^{\circ} \mathrm{C}$ ) than that for shear veins. The occurrence of extension veins that are confined to sandstone blocks and do not propagate into the surrounding matrix implies that the shale matrix was ductile, and a competence contrast existed between the sandstone blocks and the shale matrix, as described above. Shear veins crosscut shale matrices in a brittle manner, which suggests that the shear veins can be formed after lithification of shale matrices in a broad sense. Therefore, this lower temperature condition for the extension veins is 


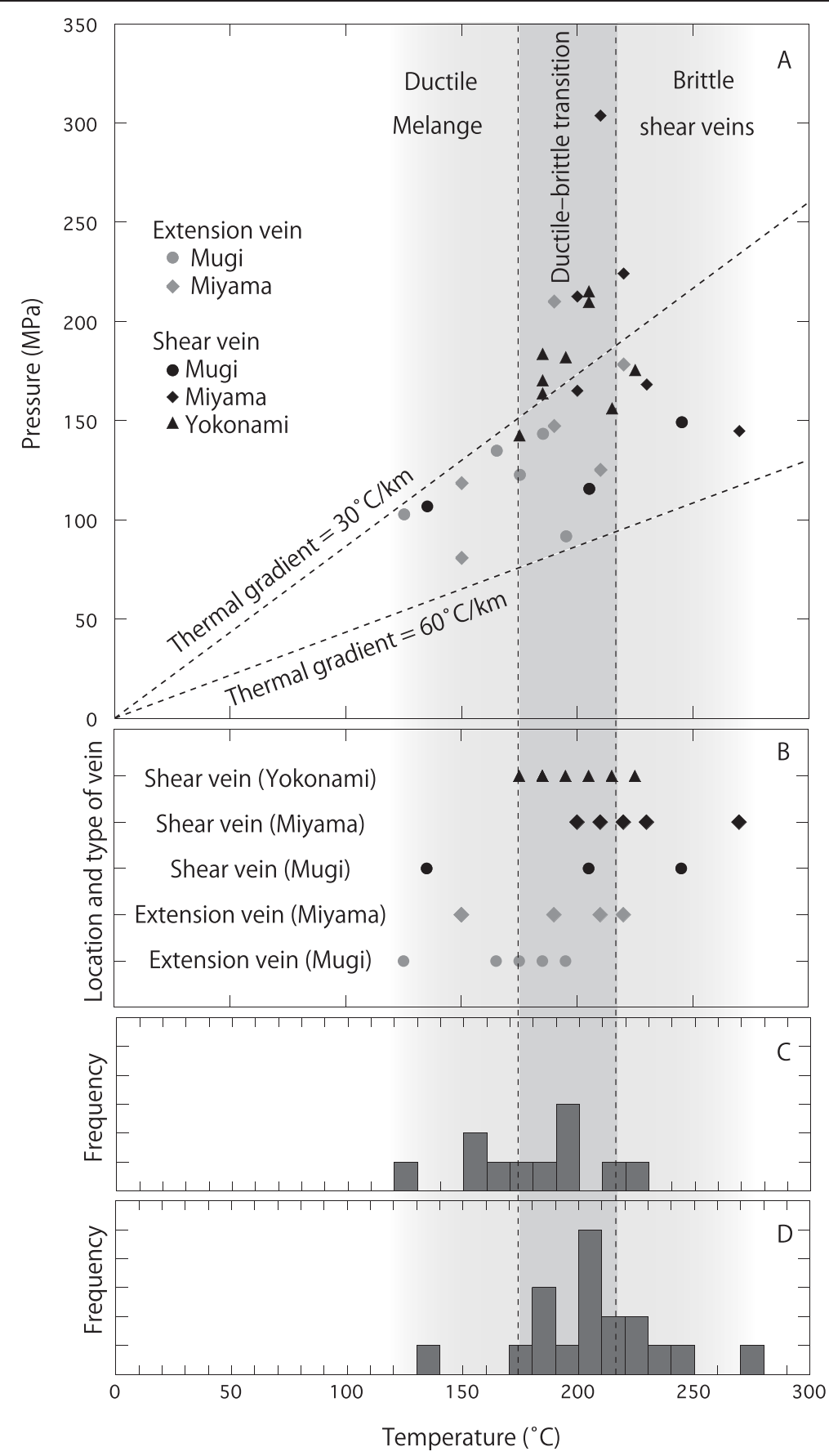

Figure 4 Pressure-temperature conditions for extension vein and shear vein formation. (A) Pressure-temperature conditions for extension vein and shear vein formation for the Mugi mélange (Matsumura et al., 2003), Miyama mélange (Hashimoto et al., 2002, 2003), and Yokonami mélange (Hashimoto et al., 2012) (locations are shown in Figure 1). Inferred temperature conditions for ductile mélange (extension veins only in sandstone); the ductile-brittle transition zone (coexistence of extension veins in sandstone blocks and shear vein) and brittle deformation (shear vein) are also indicated. See text for details. (B) Temperature conditions for each location and type of vein. (C) Histogram of temperatures for extension veins. (D) Histogram of temperatures for shear veins.

consistent with the observation of crosscutting relations between mélange fabrics and shear veins. However, overlapping temperature conditions for the extension and shear veins were identified in the temperature range between approximately 175 and $220^{\circ} \mathrm{C}$. As described above, the deformations at the time of the extension veins and shear veins are interpreted as ductile and brittle in the shale matrices, respectively. Therefore, the overlapping 
area in temperature conditions can be regarded as the shallow ductile-brittle transition zone from the ductile mélange matrix to brittle shear veins. Because the slab age is comparable in the Yokonami mélange and the Miyama formation, the temperature range of the ductile-brittle transition zone is constrained by the data from the Yokonami mélange and the Miyama formation.

\section{Discussion}

The temperature conditions and crosscutting relations for the extension and shear veins suggest that the deformations along the decollement change from ductile to brittle in a transition zone from shallow to deep. The change in deformation mechanisms is consistent with the outcrop observations that the shear veins crosscut the mélange foliation in some parts. The crosscutting relation also suggests a change in the deformation mechanism from pressure solution to frictional failure, from lower to higher temperature conditions.

The progressive change in deformation mechanism from ductile to brittle in the shallower subduction zone is probably related to lithification along the subduction interface in a broad sense. Mechanical compaction contributes to the lithification of sediments, especially in sandstone. The lithification of the sandstone is probably completed before mélange formation (Hashimoto et al., 2006). At the time the sandstone was lithified sufficiently to develop extension cracks, the shale matrix was still deforming in a ductile manner. Therefore, bulk ductile deformation was expected at the time of extension vein development. These occurrences may be associated with a relation between extensional strength of the sandstone blocks and viscosity of the shale matrix, the ratio of competent material to incompetent material, and the effect of fluid on the deformations in the ductile mélange stage. Pressure solution, a type of cementation process, can strongly contribute to lithification and strengthening of the shale matrix because of dissolution and precipitation, which reduces porosity (Angevine et al., 1982). Consequently, some shear veins that cut the shale matrix were developed after lithification of the shale matrices. Some extension veins can be formed in shale matrices after they are lithified (Figure 2A). The P-T conditions for the extension and shear veins indicate, however, that some of the shear veins were developed in the extension vein stage, which suggests that ductile and brittle deformation coexisted in a transition zone.

The transition from ductile to brittle behavior is suggested to occur in the temperature range of 175 to $220^{\circ} \mathrm{C}$ (Figure 4). The coexistence of different deformation mechanisms is not unexpected because they are controlled by competing factors such as the lithification state, strain rate, and fluid pressure. The similar occurrence of localized microfaults within a ductile mélange zone has also been reported elsewhere (e.g., Vannucchi et al., 2008; Fagereng and Sibson, 2010; Fagereng, 2011a). Fegereng and Sibson (2010) suggested that the ratio of competent sand blocks to incompetent shale matrices may control the distribution of localized microfaulting because the shear strain is concentrated in the thin shale matrices. The higher strain rate in the thin shale matrix area enhanced the development of localized microfaults in the heterogeneous mélange zone. This model depends on a heterogeneous lithification process wherein sandstone layers strengthen more rapidly and shale matrices strengthen more slowly, and the strain rate is distributed heterogeneously. The relation between shear vein distribution and thickness of the shale matrix should be examined to test the model with quantitative evaluation of the ratio between competent and incompetent materials (Fagereng, 2011b).

Saffer and Tobin (2011) suggested that high porepressure zones tend to be distributed in the temperature range of approximately 60 to $150^{\circ} \mathrm{C}$, on the basis of the fluid production rate of smectite dehydration. They suggested that the shallower ductile-brittle transition zone corresponds to the area of high pore fluid pressure because very low frequency earthquakes are observed in the area. In this study, the brittle deformation of extension veins actually exists in the ductile matrix deformation in the temperature range of 100 to $150^{\circ} \mathrm{C}$, and it was possibly caused by the overpressures (due to smectite dehydration). However, the overall trend of our data indicates that the ductile-brittle transition occurs at 175 to $220^{\circ} \mathrm{C}$, which is significantly higher than that suggested by Saffer and Tobin (2011). This compelled us to consider another mechanism for the generation of excess pore pressures at that temperature range. Kameda et al. (2011) conducted a similar calculation (not for smectite dehydration but saponite dehydration) within the hydrated basaltic basement. They suggested that fluid production from saponite dehydration is significantly high, as much as that from smectite dehydration, and that the reaction continues from approximately $150^{\circ} \mathrm{C}$ to above approximately $260^{\circ} \mathrm{C}$. Therefore, the higher temperature $\left(150\right.$ to $\left.220^{\circ} \mathrm{C}\right)$ of the ductile-brittle transition shown in this study could be explained by the high fluid pressure at least for extension veins, as Saffer and Tobin (2011) suggested, in the case that the fluid source is from saponite dehydration. For shear veins, however, the excess pore pressure is not needed. Lithification state or strain rate as discussed above are also other controlling factors that may have contributed to the development of the ductile-brittle transition in a higher temperature range. The abnormally high fluid pressure is observed only in the ductile-brittle transition zone, as shown in Figure 4. This occurrence suggests that the high pore pressure can control the area of the ductilebrittle transition zone, from the ductile mélange matrix to 
brittle shear veins, in a shallower portion along the subduction interface although the relationship between the high pore fluid pressure, lithification state, and strain rate are not well constrained. The high fluid pressure could also be the result of a change in hydrologic properties by the lithification process, such as those caused by the pressure solution or clay dehydration. The resulting high fluid pressure can weaken the preexisting shear veins as feedback processes. The volume of fluid from dehydration of smectite or saponite and their relations to deformation need to be examined in detail for different thermal gradient regimes to better understand the fluid pressure effects according to the lithification state, the ratio of competent materials in deformation features, and deformation mechanisms.

\section{Competing interests}

The authors declare that they have no competing interest.

\section{Authors' contributions}

YH designed this study and wrote the draft. NY participated in making thin sections, describing deformation structures, and the X-ray diffraction (XRD) analysis. All authors read and approved the final manuscript.

\section{Acknowledgements}

We thank Dr. M. Kinoshita and two anonymous reviewers for their constructive comments and suggestions that improved this manuscript. Part of this study was supported by the Japan Society for the Promotion of Science (JSPS) via a Grant-in-Aid for Scientific Research on Innovative Areas (70359199) and a Grant-in-Aid for Scientific Research (B) (40346698).

\section{Received: 26 February 2014 Accepted: 1 October 2014}

Published online: 16 October 2014

\section{References}

Angevine CL, Turcotte DL, Furnish MD (1982) Pressure solution lithification as a mechanism for the stick-slip behavior of faults. Tectonics 1(2):151-160

Fagereng Å, Sibson RH (2010) Mélange rheology and seismic style. Geology 38 (8):751-754. doi:10.1130/g30868.1

Fagereng $\AA$ (2011a) Fractal vein distributions within a fault-fracture mesh in an exhumed 301 accretionary mélange, Chrystalls Beach Complex, New Zealand. Journal of Structural Geology 33(5):918-927

Fagereng $\AA$ (2011b) Frequency-size distribution of competent lenses in a block-in-matrix mélange: imposed length scales of brittle deformation? Journal of Geophysical Research 116(B5), B05302. doi:10.1029/2010JB007775

Fagereng $\AA$, Toy VG (2011) Geology of the earthquake source: an introduction. Geological Society, London, Special Publications 359(1):1-16

Fisher D, Byrne T (1987) Structural evolution of underthrusted sediments, Kodiak Islands, Alaska. Tectonics 6(6):775-793

Hashimoto Y, Kimura G (1999) Underplating process from melange formation to duplexing: example from the Cretaceous Shimanto Belt, Kii Peninsula, southwest Japan. Tectonics 18(1):92-107

Hashimoto Y, Enjoji M, Sakaguchi A, Kimura G (2002) P-T conditions of cataclastic deformation associated with underplating: an example from the Cretaceous Shimanto complex, Kii Peninsula, SW Japan. Earth Planets and Space 54(11):1133-1138

Hashimoto Y, Enjoji M, Sakaguchi A, Kimura G (2003) In situ pressure-temperature conditions of a tectonic mélange: constraints from fluid inclusion analysis of syn-mélange veins. Island Arc 12(4):357-365

Hashimoto Y, Nakaya T, Ito M, Kimura G (2006) Tectonolithification of sandstone prior to the onset of seismogenic subduction zone: evidence from tectonic mélange of the Shimanto Belt, Japan. Geochemistry Geophysics Geosystems 7(6), Q06013

Hashimoto Y, Eida M, Kirikawa T, lida R, Takagi M, Furuya N, Nikaizo A, Kikuchi T, Yoshimitsu T (2012) Large amount of fluid migration around shallow seismogenic depth preserved in tectonic mélange: Yokonami mélange, the Cretaceous Shimanto Belt, Kochi, Southwest Japan. Island Arc 21(1):53-64
Hirose H, Hirahara K, Kimata F, Fujii N, Miyazaki S (1999) A slow thrust slip event following the two 1996 Hyuganada earthquakes beneath the Bungo Channel, southwest Japan. Geophysical Research Letters 26(21):3237-3240

Hyndman RD, Wang K (1993) Thermal constraints on the zone of major thrust earthquake failure: the Cascadia subduction zone. Journal of Geophysical Research 98(B2):2039-2060

Ide S, Baltay A, Beroza GC (2011) Shallow dynamic overshoot and energetic deep rupture in the $2011 M_{w} 9.0$ Tohoku-Oki earthquake. Science 332(6036):1426-1429

Ikesawa E, Sakaguchi A, Kimura G (2003) Pseudotachylyte from an ancient accretionary complex: evidence for melt generation during seismic slip along a master décollement? Geology 31(7):637-640

Ikesawa E, Kimura G, Sato K, Ikehara-Ohmori K, Kitamura Y, Yamaguchi A, Ujiie K (2005) Tectonic incorporation of the upper part of oceanic crust to overriding plate of a convergent margin: an example from the Cretaceous-early Tertiary Mugi Mélange, the Shimanto Belt, Japan. Tectonophysics 401(3-4):217-230

Ishida R, Hiramatsu Y, Matsuzawa T, Obara K (2013) Average slip rate at the transition zone on the plate interface beneath the Kii Peninsula, Japan, estimated from deep low-frequency tremors. Earth Planets and Space 65:1047-1051. doi:10.5047/eps.2013.04.003

Ito Y, Obara K (2006) Dynamic deformation of the accretionary prism excites very low frequency earthquakes. Geophysical Research Letters 33(2), L02311. doi:10.1029/2005GL025270

Ito $Y$, Hino R, Kido M, Fujimoto H, Osada Y, Inazu D, Ohta Y, linuma T, Ohzono M, Miura S (2013) Episodic slow slip events in the Japan subduction zone before the 2011 Tohoku-Oki earthquake. Tectonophysics 600:14-26

Kameda J, Yamaguchi A, Saito S, Sakuma H, Kawamura K, Kimura G (2011) A new source of water in seismogenic subduction zones. Geophysical Research Letters 38(22), L22306

Kato A, Obara K, Igarashi T, Tsuruoka H, Nakagawa S, Hirata N (2012) Propagation of slow slip leading up to the $2011 \mathrm{M}_{\mathrm{w}} 9.0$ Tohoku-Oki earthquake. Science 335(6069):705-708

Kimura G, Mukai A (1991) Underplated units in an accretionary complex: melange of the Shimanto Belt of eastern Shikoku, southwest Japan. Tectonics 10(1):31-50

Kimura G, Kitamura Y, Hashimoto Y, Yamaguchi A, Shibata T, Ujiie K, Okamoto S (2007) Transition of accretionary wedge structures around the up-dip limit of the seismogenic subduction zone. Earth and Planetary Science Letters 255(3-4):471-484

Kitamura Y, Sato K, Ikesawa E, Ikehara-Ohmori K, Kimura G, Kondo H, Ujiie K, Onishi CT, Kawabata K, Hashimoto Y (2005) Mélange and its seismogenic roof décollement: a plate boundary fault rock in the subduction zone-an example from the Shimanto Belt, Japan. Tectonics 24(5), TC5012

Knipe RJ (1989) Deformation mechanisms - recognition from natural tectonites. Journal of Structural Geology 11(1-2):127-146

Lewis JC, Byrne TB (2003) History of metamorphic fluids along outcrop-scale faults in a Paleogene accretionary prism, SW Japan: implications for prismscale hydrology. Geochemistry Geophysics Geosystems 4(9):9007

Matsumura M, Hashimoto Y, Kimura G, Ohmori-Ikehara K, Enjohji M, Ikesawa E (2003) Depth of oceanic-crust underplating in a subduction zone: inferences from fluid-inclusion analyses of crack-seal veins. Geology 31(11):1005-1008

Meneghini F, Di Toro G, Rowe CD, Moore JC, Tsutsumi A, Yamaguchi A (2010) Record of mega-earthquakes in subduction thrusts: the black fault rocks of Pasagshak Point (Kodiak Island, Alaska). Geological Society of America Bulletin 122(7-8):1280-1297

Moore JC, Saffer D (2001) Updip limit of the seismogenic zone beneath the accretionary prism of southwest Japan: an effect of diagenetic to low-grade metamorphic processes and increasing effective stress. Geology 29(2):183-186

Obara K, Hirose H, Yamamizu F, Kasahara K (2004) Episodic slow slip events accompanied by non-volcanic tremors in southwest Japan subduction zone. Geophysical Research Letters 31(23), L23602. doi:10.1029/2004GL020848

Ohmori K, Taira A, Tokuyama H, Sakaguchi A, Okamura M, Aihara A (1997) Paleothermal structure of the Shimanto accretionary prism, Shikoku, Japan: role of an out-of-sequence thrust. Geology 25(4):327-330

Onishi CT, Kimura G (1995) Change in fabric of melange in the Shimanto Belt, Japan: change in relative convergence? Tectonics 14(6):1273-1289

Osozawa S, Morimoto J, Flower MFJ (2009) "Block-in-matrix" fabrics that lack shearing but possess composite cleavage planes: a sedimentary mélange origin for the Yuwan accretionary complex in the Ryukyu island arc, Japan. Geological Society of America Bulletin 121(7-8):1190-1203

Parsons B, Sclater JG (1977) An analysis of the variation of ocean floor bathymetry and heat flow with age. Journal of Geophysical Research 82(5):803-827 
Prezbindowski DR, Larese RE (1987) Experimental stretching of fluid inclusions in calcite-implications for diagenetic studies. Geology 15(4):333-336

Roedder E (1984) Fluid inclusions. Reviews in Mineralogy 12. Mineralogical Society of America, Washington

Rogers G, Dragert H (2003) Episodic tremor and slip on the Cascadia subduction zone: the chatter of silent slip. Science 300(5627):1942-1943

Rowe CD, Moore JC, Remitti F (2013) The thickness of subduction plate boundary faults from the seafloor into the seismogenic zone. Geology 41(9):991-994

Saffer DM, Tobin HJ (2011) Hydrogeology and mechanics of subduction zone forearcs: fluid flow and pore pressure. Annual Review of Earth and Planetary Sciences 39:157-186

Saito T, Ujiiie K, Tsutsumi A, Kameda J, Shibazaki B (2013) Geological and frictional aspects of very-low-frequency earthquakes in an accretionary prism. Geophysical Research Letters 40:703-708. doi:10.1002/grl.50175

Sugioka H, Okamoto T, Nakamura T, Ishihara Y, Ito A, Obana K, Kinoshita M, Nakahigashi K, Shinohara M, Fukao Y (2012) Tsunamigenic potential of the shallow subduction plate boundary inferred from slow seismic slip. Nature Geoscience 5(6):414-418

Taira A, Katto J, Tashiro M, Okamura M, Kodama K (1988) The Shimanto Belt in Shikoku, Japan evolution of Cretaceous to Miocene accretionary prism. Modern Geology 12(5):5-46

Ujiie K, Yamaguchi H, Sakaguchi A, Toh S (2007) Pseudotachylytes in an ancient accretionary complex and implications for melt lubrication during subduction zone earthquakes. Journal of Structural Geology 29(4):599-613

Vannucchi P, Remitti F, Bettelli G (2008) Geological record of fluid flow and seismogenesis along an erosive subducting plate boundary. Nature 451 (7179):699-703

Wang K, Hu Y (2006) Accretionary prisms in subduction earthquake cycles: the theory of dynamic Coulomb wedge. Journal of Geophysical Research 111(B6), B06410

doi:10.1186/s40623-014-0141-7

Cite this article as: Hashimoto and Yamano: Geological evidence for shallow ductile-brittle transition zones along subduction interfaces: example from the Shimanto Belt, SW Japan. Earth, Planets and Space 2014 66:141

\section{Submit your manuscript to a SpringerOpen ${ }^{\circ}$ journal and benefit from:}

- Convenient online submission

- Rigorous peer review

- Immediate publication on acceptance

- Open access: articles freely available online

- High visibility within the field

- Retaining the copyright to your article

Submit your next manuscript at $>$ springeropen.com 